\title{
Synthesis and Characterization of CaTiO3- LnAlO3(Ln=La, Nd) Ceramics Manufactured by Reaction Sintering Method
}

\section{Shicheng Zhou}

Guilin University of Technology

\section{Qiang Wu}

Guilin University of Technology

Hanrui Xu

Guilin University of Technology

\section{Xiaowen Luan}

Guilin University of Technology

\section{Sang $\mathrm{Hu}$}

Guilin University of Technology

Xianjie Zhou

Guilin University of Technology

\section{Sen $\mathrm{He}$}

Guilin University of Technology

\section{Xi Wang}

Guilin University of Technology

Hailin Zhang

Guilin University of Technology

\section{Xiuli Chen}

Guilin University of Technology

Huanfu Zhou ( $\square$ zhouhuanfu@163.com )

Guilin University of Technology

\section{Research Article}

Keywords: CaTiO3-LnAlO3(Ln=La, Nd) ceramics, Reaction sintering method, Microwave dielectric properties

Posted Date: April 7th, 2021

DOI: https://doi.org/10.21203/rs.3.rs-395144/v1 
License: (c) (i) This work is licensed under a Creative Commons Attribution 4.0 International License. Read Full License 


\title{
Synthesis and characterization of $\mathrm{CaTiO}_{3}-\mathrm{LnAlO}_{3}(\mathrm{Ln}=\mathrm{La}, \mathrm{Nd})$ ceramics manufactured by reaction sintering method
}

Shicheng Zhou , Qiang Wu †, Hanrui Xu, Xiaowen Luan, Sang Hu, Xianjie Zhou, Sen He, Xi Wang, Hailin Zhang, Xiuli Chen, Huanfu Zhou*.

Collaborative Innovation Centre for Exploration of Hidden Nonferrous Metal Deposits and Development of New Materials in Guangxi, Key Laboratory of Nonferrous Materials and New Processing Technology, Ministry of Education, School of Materials Science and Engineering, Guilin University of Technology, Guilin 541004, China.

\begin{abstract}
$\mathrm{CaTiO}_{3}-\mathrm{LnAlO}_{3}(\mathrm{Ln}=\mathrm{La}, \mathrm{Nd})$ ceramics were manufactured by reaction-sintering for produce low cost and high efficiency materials. Using reaction-sintering method to manufacture these ceramics, which have excellent comprehensive properties. The subtle variations on densification behavior, phase transformation, phase composition, microstructure evolution and performances of $\mathrm{CaTiO}_{3}-\mathrm{LnAlO}_{3}(\mathrm{Ln}=\mathrm{La}, \mathrm{Nd})$ ceramics were studied systematically. The XRD pattern indicates that the $\mathrm{Ca}_{0.61} \mathrm{La}_{0.39} \mathrm{Al}_{0.39} \mathrm{Ti}_{0.61} \mathrm{O}_{3}$ phase and $\mathrm{Ca}_{0.7} \mathrm{Nd}_{0.3} \mathrm{Ti}_{0.7} \mathrm{Al}_{0.3} \mathrm{O}_{3}$ phase were generated under certain environmental conditions respectively. The ceramics exhibited excellent performance parameters: when $\varepsilon_{r}$ is $42.03(45635)$, the quality factor is $45500 \mathrm{GHz}$ (45 635) In addition, even in the environment of large temperature changes the ceramics can still maintain good performance. In conclusion, the reaction sintering method is an economic, convenient, available preparation means of making the $\mathrm{CaTiO}_{3}-$

$\dagger$ These authors have equal contribution to this work

${ }^{*}$ Corresponding author, E-mail: zhouhuanfu@163.com
\end{abstract}


$\mathrm{LnAlO}_{3}(\mathrm{Ln}=\mathrm{La}, \mathrm{Nd})$ ceramics and has broad prospects of application and development.

Keywords: $\mathrm{CaTiO}_{3}-\mathrm{LnAlO}_{3}(\mathrm{Ln}=\mathrm{La}, \mathrm{Nd})$ ceramics; Reaction sintering method; Microwave dielectric properties 


\section{Introduction}

The wireless communication industries led by microwave communication technology are developing at a rapid pace. A better and serious request about the performance of the functional ceramics was also put forward by this prospect.[1-3]. Because of smallness, lightness, and cheapness microwave dielectric ceramics are excellent candidate materials for communication technologies [4-6].

In actual application, process flow and production cost are factors that must be considered. High production expenses will limit the prospect of numerous microwave ceramics, as $(1-x) \mathrm{ZnNb}_{2} \mathrm{O}_{6}-x \mathrm{Ba}\left(\mathrm{Zn}_{1 / 3} \mathrm{Nb}_{2 / 3}\right) \mathrm{O}_{3}[7]$. For the sake of practical application, appropriate raw materials and efficient processes are necessary. Suvorov et al. reported that although the $\mathrm{CaTiO}_{3}$ ceramics demonstrate favorable microwave dielectric properties $\left(\varepsilon_{r}=170\right)$, its practical application is hindered by quality factor $(Q \times f=3500$ $\mathrm{GHz})$ and temperature coefficient $\left(\tau_{f}=+800 \mathrm{ppm} /{ }^{\circ} \mathrm{C}\right)$. It is easy to acquire useful microwave dielectric ceramics via synthesizing two perovskite structure compounds together[8]. $\mathrm{CaTiO}_{3}-\mathrm{LnAlO}_{3}(\mathrm{Ln}=\mathrm{La}, \mathrm{Nd})$ solid solution ceramics exhibited good performances, which preserves excellent comprehensive properties: $\varepsilon_{r} 37 \sim 44, Q \times f 41$ 000 47 000GHZ, $\tau_{f}-1.5 \sim 6 \mathrm{ppm} /{ }^{\circ} \mathrm{C}$. Ravi et al. reported that $0.7 \mathrm{CaTiO}_{3}-0.3 \mathrm{LaAlO}_{3}$ ceramics doped with $0.25 \mathrm{wt} \% \mathrm{Al}_{2} \mathrm{O}_{3}$ sintered at $1500^{\circ} \mathrm{C}$, and the ceramic showed great performance parameters: $\varepsilon_{r}=46, Q \times f=38289 \mathrm{GHz}$, and $\tau_{f}=+12 \mathrm{ppm} /{ }^{\circ} \mathrm{C}[9]$.

In this work, using reaction sintering method to manufacture $\mathrm{CaTiO}_{3}$ $\mathrm{LnAlO}_{3}(\mathrm{Ln}=\mathrm{La}, \mathrm{Nd})$ ceramics to simplify experimental procedures and optimize the dielectric properties. Also, the solid-state reaction mechanism of the $\mathrm{CaTiO}_{3}-$ $\mathrm{LnAlO}_{3}(\mathrm{Ln}=\mathrm{La}, \mathrm{Nd})$ solid solution was also investigated, which determine the origin 
of the intermediate phase.

\section{Materials and methods}

$\mathrm{CaTiO}_{3}-\mathrm{LnAlO}_{3}(\mathrm{Ln}=\mathrm{La}, \mathrm{Nd})$ ceramic samples were made from high purity materials $(\geq 99 \%)$ including $\mathrm{CaCO}_{3}, \mathrm{TiO}_{2}, \mathrm{Al}_{2} \mathrm{O}_{3}, \mathrm{La}_{2} \mathrm{O}_{3}$, and $\mathrm{Nd}_{2} \mathrm{O}_{3}$, therefore preprocessing of high purity raw materials is the foremost section in fabrication of high quality dielectric ceramics, especially $\mathrm{La}_{2} \mathrm{O}_{3}$, and $\mathrm{Nd}_{2} \mathrm{O}_{3}$. Put $\mathrm{La}_{2} \mathrm{O}_{3}$, and $\mathrm{Nd}_{2} \mathrm{O}_{3}$ into muffle furnace at $900^{\circ} \mathrm{C}$ for two hours respectively, and the mole ratios of $\mathrm{CaTiO}_{3}-$ $\mathrm{LaAlO}_{3}$ and $\mathrm{CaTiO}_{3}-\mathrm{NdAlO}_{3}$ were determined to be 0.675:0.325 and 0.695:0.305, respectively. The powder was blended with zirconia pellets in alcoholic medium for 4 h. After drying in an oven, samples in cylindrical molds with a diameter of $10 \mathrm{~mm}$ and a height of $5 \mathrm{~mm}$ were fabricated at $20 \mathrm{MPa}$. Finally, they have been sintered from $1475^{\circ} \mathrm{C}$ to $1575^{\circ} \mathrm{C}$ with a gradient of $25^{\circ} \mathrm{C}$ for $6 \mathrm{~h}$ respectively.

Using the X-ray diffraction (Model X'Pert PRO, PANalytical, Almelo, Holland) with $\mathrm{Cu} \mathrm{K} \mathrm{K}_{\alpha}$ radiation at $40 \mathrm{kV}$ and $40 \mathrm{~mA}\left(5^{\circ} \leq 2 \theta \leq 80^{\circ}\right)$ to analyze the microstructure and crystalline of the ceramics. The surface topography and crystal size were observed with SEM (Model JSM6380-LV SEM, JEOL, Tokyo, Japan). Performance parameters of specimens were acquired by using the network analyzer (Model E5071 CENA, Agilent Co, California, USA, $300 \mathrm{KHz}-20 \mathrm{GHz}$ ). The $\tau_{f}$ values of the samples were measured from the resonant frequencies at $25^{\circ} \mathrm{C}$ to $85^{\circ} \mathrm{C}$ and was defined as:

$$
t_{f}=\left(f_{2}-f_{1}\right) / f_{1}\left(T-T_{0}\right)
$$

where $f_{2}$ and $f_{1}$ are the resonance frequencies at $85^{\circ} \mathrm{C}$ and $25^{\circ} \mathrm{C}$, respectively.

\section{Results and discussion}


Figure 1 presents the XRD spectrum of CTLA and CTNA samples sintered from 1100 to $1575^{\circ} \mathrm{C}$ for $6 \mathrm{~h}$, respectively. As shown in Fig1(a), the XRD spectrum of the CTLA samples revealed that there are two types of phase $\mathrm{CaTiO}_{3}(\mathrm{PDF} \# 96-900-2802)$ and $\mathrm{LaAlO}_{3}(\mathrm{PDF} \# 01-082-0478)$ at $1100^{\circ} \mathrm{C}$. As the temperature is $1475^{\circ} \mathrm{C}$, two phases are completely form a solid solution. All diffraction peaks are homogeneous $\mathrm{Ca}_{0.61} \mathrm{La}_{0.39} \mathrm{Al}_{0.39} \mathrm{Ti}_{0.61} \mathrm{O}_{3}$ main phase, corresponding to the tetragonal perovskite structure (PDF: 00-052-1773), belonging to the $\mathrm{P} 4{ }_{2} 2{ }_{1} 2$ space group[10]. The tendency of Fig1(b) is similar as Fig1(a). The ceramic specimen was composed of both $\mathrm{CaTiO}_{3}$ and $\mathrm{NdAlO}_{3}$ phases, and the secondary phase gradually disappeared at $1200^{\circ} \mathrm{C}[11]$. Upon further increase of the temperature to $1450{ }^{\circ} \mathrm{C}$, the main peak of the CTNA ceramics appeared at $2 \theta=33.2^{\circ}$, which matches well with the $2 \theta$ value of the $\mathrm{Ca}_{0.7} \mathrm{Nd}_{0.3} \mathrm{Ti}_{0.7} \mathrm{Al}_{0.3} \mathrm{O}_{3}$ phase (PDF: 96-153-3888), belonging to the Pnma space group[12-14]. Using the GASA software could further enhance the fitting accuracy and ascertain the cation position of the samples accurately, the refinement results are shown in Fig. 2. Both samples exhibited a single $\mathrm{CaTiO}_{3}$ phase with a orthorhombic structure in the Pbmn model, and the lattice parameters of this ceramic are as follows: $a=$ 5.358(6) $\AA, \mathrm{b}=7.593(10) \AA, \mathrm{c}=5.394(5) \AA$, and $\alpha=\beta=\gamma=90^{\circ}$. The small R-values (CTLA: $R p=4.09 \%, R w p=7.43 \%$; CTNA: $R p=4.17 \%, R w p=7.57 \%$ ) manifest that the XRD result matched faultlessly consistent with $\mathrm{CaTiO}_{3}$ (PDF: 75-0437) with orthorhombic structure, which indicates that CTLA and CTNA ceramics are fused to form a complete solid solution. $\mathrm{Ca}^{2+}, \mathrm{La}^{3+}, \mathrm{Nd}^{3+}$ take up the A-site of the oxygen octahedron, and $\mathrm{Ti}^{4+}, \mathrm{Al}^{3+}$ take up the B-site of the oxygen octahedron[15, 16]. 
Figure 3 shows the SEM micrographs of $\mathrm{CaTiO}_{3}-\mathrm{LnAlO}_{3}(\mathrm{Ln}=\mathrm{La}, \mathrm{Nd})$ samples sintered at various temperatures. The micromorphology is variable with the changing of temperature. When the sintering temperatures were less than $1450^{\circ} \mathrm{C}$, the particles are composed of small crystal and the structure is not dense enough, which manifest that low temperature cannot provide enough energy for grain growth[17-19]. Raising the temperature again the samples surface becomes more compact and homogeneous and few grain boundaries appears. When the sintering temperature exceeds $1525^{\circ} \mathrm{C}$, there were only a few pores in the sample[20,21]. The above results shown that $\mathrm{CaTiO}_{3}-\mathrm{LnAlO}_{3}(\mathrm{Ln}=\mathrm{La}, \mathrm{Nd})$ ceramics could keep excellent performance in a wide temperature range. Using EDS to verify the molar ratios of elements in $\mathrm{CaTiO}_{3}$ $\mathrm{LnAlO}_{3}(\mathrm{Ln}=\mathrm{La}, \mathrm{Nd})$ ceramics, which verifies the analysis and conclusion of XDR. Table 1 includes the results of EDS in detail. All samples contain only $\mathrm{Ca}, \mathrm{Ti}, \mathrm{Al}, \mathrm{La} / \mathrm{Nd}$ and $\mathrm{O}$ elements. The calculated result of $\mathrm{Ca} / \mathrm{Al}$ atomic number ratio is same with the main crystal phase. For example, the atomic number ratio of $\mathrm{Ca} / \mathrm{Ti}$ to $\mathrm{Nd} / \mathrm{Al}$ is close to 7:3 in CTNA ceramics, which is very consistent with the stoichiometric ratio of $\mathrm{Ca}_{0.7} \mathrm{Nd}_{0.3} \mathrm{Ti}_{0.7} \mathrm{Al}_{0.3} \mathrm{O}_{3}$ phase.

Fig.4 including the curves of $\rho, \varepsilon_{r}, Q \times f$ and $\tau_{f}$ of $\mathrm{CaTiO}_{3}-\mathrm{LnAlO}_{3}(\mathrm{Ln}=\mathrm{La}, \mathrm{Nd})$ ceramics with the changing of the sintering temperature. The bulk densities of CTLA and CTNA ceramics were $4.47-4.68 \mathrm{~g} / \mathrm{cm}^{3}$ and $4.48-4.80 \mathrm{~g} / \mathrm{cm}^{3}$. With the rise of temperature ,the bulk densities $\rho$ of CTNA ceramics and CTLA ceramics firstly rose due to the growth of grains, reaching the maximum values at a selected temperature, and then its density declines gradually due to the inner defects caused by extra-high 
temperature. When the temperature gradually increases to the ideal temperature, the ceramic grains grow and discharge the pores inside the ceramic, making microstructure of the ceramic more compact. and reaching the maximum. When the temperature exceeds the optimal temperature, the phenomenon of overburning occurs. The grain growth rate is too fast to discharge the pores inside the ceramic in time, contributing to the decline in the density[22-24].

As the sintering temperature increases, the dielectric constant of $\mathrm{CaTiO}_{3}$ $\mathrm{LnAlO}_{3}(\mathrm{Ln}=\mathrm{La}, \mathrm{Nd})$ ceramics reaches a maximum value at the optimum temperature and then decreases. The trend is similar to the relative density. The high density of ceramics is accompanied by high polarizability and thus to an increase in polarization intensity[2, 25]. The relationship between the dielectric constant and the dielectric polarizability and molar volume fraction of the materials can be explained clearly by the Clausius-Mossotti formula used in the literature as follows:

$$
\varepsilon \mathrm{th}=\frac{3 \mathrm{Vm}+8 \pi \alpha \mathrm{D}}{3 \mathrm{Vm}-4 \pi \alpha \mathrm{D}}
$$

where $V m$ is the cell volume of the $\mathrm{Ca}_{0.61} \mathrm{La}_{0.39} \mathrm{Al}_{0.39} \mathrm{Ti}_{0.61} \mathrm{O}_{3}$ and $\mathrm{Ca}_{0.7} \mathrm{Nd}_{0.3} \mathrm{Ti}_{0.7} \mathrm{Al}_{0.3} \mathrm{O}_{3}$ molecule, and $\alpha$ is their polarization rates. The total ion polarization rate of $\mathrm{Ca}_{0.61} \mathrm{La}_{0.39} \mathrm{Al}_{0.39} \mathrm{Ti}_{0.61} \mathrm{O}_{3}$ and $\mathrm{Ca}_{0.7} \mathrm{Nd}_{0.3} \mathrm{Ti}_{0.7} \mathrm{Al}_{0.3} \mathrm{O}_{3}$ can be calculated as follows:

$$
\begin{gathered}
\alpha\left(\mathrm{Ca}_{0.61} \mathrm{La}_{0.39} \mathrm{Al}_{0.39} \mathrm{Ti}_{0.61} \mathrm{O}_{3}\right)=0.61 \alpha\left(\mathrm{Ca}^{2+}\right)+0.61 \alpha\left(\mathrm{Ti}^{4+}\right)+0.39 \alpha\left(\mathrm{La}^{3+}\right) \\
+0.39 \alpha\left(\mathrm{Al}^{3+}\right)+3 \alpha\left(\mathrm{O}^{2-}\right) \\
\alpha\left(\mathrm{Ca}_{0.7} \mathrm{Nd}_{0.3} \mathrm{Ti}_{0.7} \mathrm{Al}_{0.3} \mathrm{O}_{3}\right)=0.7203(3) \\
+3 \alpha\left(\mathrm{Ca}^{2-}\right) \\
\text { Where } \alpha\left(\mathrm{Ca}^{2+}\right)=3.16 \AA^{3}, \alpha\left(\mathrm{Ti}^{4+}\right)=2.93 \AA^{3}, \alpha\left(\mathrm{La}^{3+}\right)=6.07 \AA^{3}, \alpha\left(\mathrm{Nd}^{3+}\right)=5.01 \AA^{3}, \alpha\left(\mathrm{Al}^{3+}\right)+0.3 \alpha\left(\mathrm{Nd}^{3+}\right)+0.3 \alpha\left(\mathrm{Al}^{3+}\right) \\
=0.79 \AA^{3} \text { and } \alpha\left(\mathrm{O}^{2-}\right)=2.01 \AA^{3} . \text { The theoretical permittivity of CTLA and CTNA were }
\end{gathered}
$$


40.86 and 31.9, respectively. Due to the high dielectric constant of calcium titanate and the grain priority growth, there is a large difference between the measured and calculated values of $\varepsilon[26]$.

There are two types of materials losses at microwave frequency: on the one hand the intrinsic loss mainly determined by the lattice vibration mode could influence the properties of materials, on the other hand the external loss determined by the second phase, oxygen vacancies, grain size and densities could also affect the properties of materials[27, 28]. In the same system, the excellent performance of materials depends on the grain size and the number of pores. Therefore, with increasing temperature, the variation of $Q \times f$ value is close to the dielectric constant, which the maximum $Q \times f$ values of $\mathrm{CaTiO}_{3}-\mathrm{LnAlO}_{3}(\mathrm{Ln}=\mathrm{La}, \mathrm{Nd})$ ceramics are 46,269 $\mathrm{GHz}$ and 45,635 GHz, respectively. According to the Fig 4, the quality factor of $\mathrm{CaTiO}_{3}-\mathrm{LnAlO}_{3}(\mathrm{Ln}=\mathrm{La}, \mathrm{Nd})$ ceramics is greater than 41,000 under different ranges of temperature. The $\tau_{f}$ values of $\mathrm{CaTiO}_{3}-\mathrm{LnAlO}_{3}(\mathrm{Ln}=\mathrm{La}, \mathrm{Nd})$ ceramics remain stable at -1.5 to $6 \mathrm{ppm} /{ }^{\circ} \mathrm{C}$ no matter how the temperature changes. The fluctuations in their $\tau_{\mathrm{f}}$ values are mainly caused by grain size, porosity, oxygen vacancies, etc[29, 30]. These indicate that the $\mathrm{CaTiO}_{3}-$ $\mathrm{LnAlO}_{3}(\mathrm{Ln}=\mathrm{La}$, Nd) ceramics has achieved excellent performance in a wide temperature range.

\section{Conclusion}

The densification behavior, phase transformation, phase composition, microstructure evolution and performances of $\mathrm{CaTiO}_{3}-\mathrm{LnAlO}_{3}(\mathrm{Ln}=\mathrm{La}, \mathrm{Nd})$ have been reported by the reaction-sintering method. Solid-solutions with tetragonal and 
orthorhombic perovskite structures were formed. The $\mathrm{CaTiO}_{3}-\mathrm{LnAlO}_{3}(\mathrm{Ln}=\mathrm{La}, \mathrm{Nd})$ ceramics exhibited the excellent performances as the temperature is between 1475 and $1575^{\circ} \mathrm{C}$. The ceramics sintered at 1500 and $1525^{\circ} \mathrm{C}$ indicated that it has considerable performance parameters CTNA: $Q \times f=45635 \mathrm{GHz}, \varepsilon_{r}=39.1$, and $\tau_{f}=-1.48 \mathrm{ppm} /{ }^{\circ} \mathrm{C}$; CTLA: $Q \times f=46269 \mathrm{GHz}, \varepsilon_{r}=44.03$, and $\left.\tau_{f}=2.63 \mathrm{ppm} /{ }^{\circ} \mathrm{C}\right)$. The preparation of $\mathrm{CaTiO}_{3}-\mathrm{LnAlO}_{3}(\mathrm{Ln}=\mathrm{La}, \mathrm{Nd})$ ceramics by reaction-sintering method has the advantages of simple preparation process, low preparation cost, and wide sintering temperature range, which showing good prospects for industrial applications.

\section{Acknowledgment}

This work was supported by the Natural Science Foundation of China (Nos.

61761015 and 11664008) and the Natural Science Foundation of Guangxi (Nos. 2017GXNSFFA198011,2018GXNSFFA050001, and 2017GXNSFDA198027) and High-Level Innovation Team and Outstanding Scholar Program of Guangxi Institutes. 


\section{References}

[1] X. L. Chen, H. F. Zhou, L. A. Fang, X. B. LiuY. L. Wang Microwave dielectric properties and its compatibility with silver electrode of $\mathrm{Li}_{2} \mathrm{MgTi}_{3} \mathrm{O}_{8}$ ceramics. $\mathrm{J}$. Alloy. Compd. 2011, 509 (19): 5829-5832.

[2] K. G. Wang, H. F. Zhou, X. B. Liu, W. D. Sun, X. L. ChenH. Ruan A lithium aluminium borate composite microwave dielectric ceramic with low permittivity, near-zero shrinkage, and low sintering temperature. J. Eur. Ceram. Soc. 2019, 39 (4): 1122-1126.

[3] H. F. Zhou, X. H. Tan, J. Huang, N. Wang, G. C. FanX. L. Chen Phase structure, sintering behavior and adjustable microwave dielectric properties of $\mathrm{Mg}_{1-}$ ${ }_{x} \mathrm{Li}_{2 x} \mathrm{Ti}_{x} \mathrm{O}_{1+2 x}$ solid solution ceramics. J. Alloy. Compd. 2017, 696: 1255-1259.

[4] H. B. Bafrooei, E. T. Nassaj, T. Ebadzadeh, C. F. Hu, A. Sayyadi-ShahrakiT. Kolodiazhnyi Sintering behavior and microwave dielectric characteristics of $\mathrm{ZnTiNb}_{2} \mathrm{O}_{8}$ ceramics achieved by reaction sintering of $\mathrm{ZnO}-\mathrm{TiO}_{2}-\mathrm{Nb}_{2} \mathrm{O}_{5}$ nanosized powders. Ceram. Int. 2016, 42 (2): 3296-3303.

[5] M. Bari, E. Taheri-NassajH. Taghipour-Armaki Phase Evolution, Microstructure, and Microwave Dielectric Properties of Reaction-Sintered $\mathrm{Li}_{2} \mathrm{ZnTi}_{3} \mathrm{O}_{8}$ Ceramic Obtained Using Nanosized $\mathrm{TiO}_{2}$ Reagent. J. Electron. Mater. 2015, 44 (10): 36703676.

[6] P. Gogoi, L. R. SinghD. Pamu Characterization of $\mathrm{Zn}$ doped $\mathrm{MgTiO}_{3}$ ceramics: an approach for RF capacitor applications. J. Mater. Sci.-Mater. Electron. 2017, 28 (16): 11712-11721. 
[7] W. T. Xie, Q. X. Jiang, Q. L. Cao, H. Q. Zhou, L. C. RenX. F. Luo Microwave dielectric properties of $(1-x) \mathrm{ZnNb}_{2} \mathrm{O}_{6}-x \mathrm{Ba}\left(\mathrm{Zn}_{1 / 3} \mathrm{Nb}_{2 / 3}\right) \mathrm{O}_{3}$ compound ceramic with near zero temperature coefficient. J. Mater. Sci.-Mater. Electron. 2018, 29 (3): $2170-2174$.

[8] E. A. Tugova, A. V. Travitskov, M. V. Tomkovich, V. V. SokolovE. A. Nenasheva Solid-Phase Synthesis and Dielectric Properties of Materials Based on $\mathrm{LaAlO}_{3}$ $\mathrm{CaTiO}_{3}$ System. Russ. J. Appl. Chem. 2017, 90 (11): 1738-1745.

[9] J. Jiang, D. H. Fang, C. Lu, Z. M. Dou, G. Wang, F. ZhangT. J. Zhang Solid-state reaction mechanism and microwave dielectric properties of $\mathrm{CaTiO}_{3}-\mathrm{LaAlO}_{3}$ ceramics. J. Alloy. Compd. 2015, 638: 443-447.

[10] G. Wang, J. Jiang, Z. M. Dou, F. ZhangT. J. Zhang Sintering behavior and microwave dielectric properties of $0.67 \mathrm{CaTiO}_{(3)}-0.33 \mathrm{LaAlO}_{(3)}$ ceramics modified by $\mathrm{B}_{2} \mathrm{O}_{3}-\mathrm{Li}_{2} \mathrm{O}-\mathrm{Al}_{2} \mathrm{O}_{3}$ and $\mathrm{CeO}_{2}$. Ceram. Int. 2016, 42 (9): 11003-11009.

[11] D. Li, C. Y. Luo, Y. B. Xu, L. Wu, H. X. Wang, S. J. Shi, F. R. LingJ. Q. Yao The effect of optical pump on the absorption coefficient of $0.65 \mathrm{CaTiO}_{(3)}-0.35 \mathrm{NdAlO}_{(3)}$ ceramics in terahertz range. Opt. Mater. 2018, 75: 280-284.

[12] X. Y. Yang, X. H. Wang, M. Huang, S. P. ZhangL. T. Li Synthesis and characterization of $\mathrm{CaTiO}_{3}-(\mathrm{Sm}, \mathrm{Nd}) \mathrm{AlO}_{3}$ microwave ceramics via sol-gel method. J. Sol-Gel Sci. Technol. 2014, 69 (1): 61-66.

[13] M. H. Weng, C. T. Liauh, S. M. Lin, H. H. WangR. Y. Yang Sintering Behaviors, Microstructure, and Microwave Dielectric Properties of $\mathrm{CaTiO}_{3}-\mathrm{LaAlO}_{3}$ Ceramics Using $\mathrm{CuO} / \mathrm{B}_{2} \mathrm{O}_{3}$ Additions. Materials 2019, 12 (24): 12. 
[14] Z. M. Dou, G. Wang, J. Jiang, F. ZhangT. J. Zhang Understanding microwave dielectric properties of $(1-\mathrm{x}) \mathrm{CaTiO}_{3}-\mathrm{xLaAlO}_{(3)}$ ceramics in terms of $\mathrm{A} / \mathrm{B}$-site ionicparameters. J. Adv. Ceram. 2017, 6 (1): 20-26.

[15] Sintering Behavior and Microwave Dielectric Properties of (Ca, La)(Ti, $\mathrm{Al} \mathrm{O}_{3}$ Ceramics.

[16] G. H. Hou, Z. H. WangF. Zhang Sintering behavior and microwave dielectric properties of (1-x)CaTiO $3-x \mathrm{LaAlO}_{(3)}$ ceramics. J. Rare Earths 2011, 29 (2): 160163.

[17] P. Ruan, P. Liu, B. C. Guo, F. LiZ. F. Fu Microwave dielectric properties of ZnO$\mathrm{Nb}_{2} \mathrm{O}_{5}-x \mathrm{TiO}_{(2)}$ ceramics prepared by reaction-sintering process. J. Mater. Sci.-Mater. Electron. 2016, 27 (5): 4201-4205.

[18] G. Wang, D. N. Zhang, G. W. Gan, Y. Yang, Y. H. Rao, F. Xu, X. Huang, Y. L. Liao, J. Li, C. Liu, L. C. JinH. W. Zhang Synthesis, crystal structure and low loss of $\mathrm{Li}_{3} \mathrm{Mg}_{2} \mathrm{NbO}_{6}$ ceramics by reaction sintering process. Ceram. Int. 2019, 45 (16): 19766-19770.

[19] G. G. Yao Synthesis and microwave dielectric properties of $\mathrm{Li}_{2} \mathrm{ZnTi}_{3} \mathrm{O}_{8}$ ceramics by the reaction-sintering process. J. Ceram. Process. Res. 2015, 16 (1): 41-44.

[20] H. F. Zhou, H. Wang, Y. H. Chen, K. C. LiX. Yao Microwave Dielectric Properties of $\mathrm{BaTi}_{5} \mathrm{O}_{11}$ Ceramics Prepared by Reaction-Sintering Process with the Addition of CuO. J. Am. Ceram. Soc. 2008, 91 (10): 3444-3447.

[21] J. M. Li, P. Xu, T. QiuL. C. Yao Sintering characteristics and microwave dielectric properties of $0.5 \mathrm{Ca}(0.6) \mathrm{La}(0.267) \mathrm{TiO}_{(3)}-0.5 \mathrm{Ca}\left(\mathrm{Mg}_{1 / 3} \mathrm{Nb}_{2 / 3}\right) \mathrm{O}_{3}$ ceramics prepared by 
reaction-sintering process. J. Rare Earths 2018, 36 (4): 404-408.

[22] J. D. Guo, W. B. Ma, M. J. Ma, H. D. Zhao, Y. X. YangJ. F. Gao Sintering characteristic and microwave dielectric properties of ultra-low loss $\mathrm{Li}_{2} \mathrm{Mg}_{3} \mathrm{TiO}_{6}$ ceramic prepared by reaction-sintering process. J. Mater. Sci.-Mater. Electron. 2018, 29 (5): $3640-3647$.

[23] B. C. Guo, P. Liu, Z. F. Fu, P. RuanX. J. Bai Effect of Preparation Methods on Microstructures and Microwave Dielectric Properties of $\mathrm{CdWO}_{4}$ Ceramics. Integr. Ferroelectr. 2015, 167 (1): 107-114.

[24] L. He, H. T. Yu, M. S. Zeng, E. Z. Li, J. S. LiuS. R. Zhang Phase compositions and microwave dielectric properties of $\mathrm{MgTiO}_{3}$-based ceramics obtained by reactionsintering method. J. Electroceram. 2018, 40 (4): 360-364.

[25] P. Riazikhoei, F. AzoughR. Freer The influence of $\mathrm{ZnNb}_{2} \mathrm{O}_{6}$ on the microwave dielectric properties of $\mathrm{ZM}_{(2)} \mathrm{O}_{(6)}$ ceramics. J. Am. Ceram. Soc. 2006, 89 (1): 216223.

[26] M. J. Wu, Y. C. Zhang, J. D. ChenM. Q. Xiang Microwave dielectric properties of sol-gel derived $\mathrm{NiZrNb}_{2} \mathrm{O}_{8}$ ceramics. J. Alloy. Compd. 2018, 747: 394-400.

[27] C. F. Xing, Y. H. Zhang, B. J. Tao, H. T. WuY. Y. Zhou Crystal structure, infrared spectra and microwave dielectric properties of low-firing $\mathrm{La}_{2} \mathrm{Zr}_{3}\left(\mathrm{MoO}_{4}\right)_{(9)}$ ceramics prepared by reaction-sintering process. Ceram. Int. 2019, 45 (17): 22376-22382.

[28] H. T. Yu, T. Luo, L. HeJ. S. Liu Effect of $\mathrm{ZnO}$ on $\mathrm{Mg}_{2} \mathrm{TiO}_{4}-\mathrm{MgTiO}_{3}-\mathrm{CaTiO}_{3}$ microwave dielectric ceramics prepared by reaction sintering route. Adv. Appl. Ceram. 2019, 118 (3): 98-105. 
[29] L. M. Zhang, Y. Chang, M. Xin, X. F. Luo, H. J. Tao, Y. Fu, P. Z. LiH. Q. Zhou Synthesis of $0.65 \mathrm{CaTiO}_{(3)}-0.35 \mathrm{SmAlO}_{(3)}$ ceramics and effects of $\mathrm{La}_{2} \mathrm{O}_{3} / \mathrm{SrO}$ doping on their microwave dielectric properties. J. Mater. Sci.-Mater. Electron. 2018, 29 (24): 21205-21212.

[30] H. F. Zhou, W. D. Sun, X. B. Liu, K. G. Wang, H. RuanX. L. Chen Microwave dielectric properties of $\mathrm{LiCa}_{3} \mathrm{ZnV}_{3} \mathrm{O}_{12}$ and $\mathrm{NaCa}_{2} \mathrm{Mg}_{2} \mathrm{~V}_{3} \mathrm{O}_{12}$ ceramics prepared by reaction-sintering. Ceram. Int. 2019, 45 (2): 2629-2634. 


\section{Figure Captions}

Figure 1. XRD patterns of CTLA and CTNA ceramics sintered at 1100 to $1575^{\circ} \mathrm{C}$ for $6 h$.

Figure 2. Rietveld refinement of the room temperature $\mathrm{XRD}$ patterns of $\mathrm{CaTiO}_{3}$ $\mathrm{LnAlO}_{3}(\mathrm{Ln}=\mathrm{La}, \mathrm{Nd})$ ceramic $\left(\mathrm{CTLA}: R p=4.09 \%, R w p=7.43 \%, \chi^{2}=15.55\right.$; CTNA: $\left.\mathrm{R}_{\mathrm{wp}}=7.57 \%, \mathrm{R}_{\mathrm{p}}=4.17 \%, \chi^{2}=11.08\right)$.

Figure 3. $\mathrm{SEM}$ micrographs of $\mathrm{CaTiO}_{3}-\mathrm{LnAlO}_{3}(\mathrm{Ln}=\mathrm{La}, \mathrm{Nd})$ ceramics sintered at 1475 to $1550^{\circ} \mathrm{C}$ for $6 \mathrm{~h}$.

Figure 4. The curves of $\rho, \varepsilon_{r}, Q \times f$ and $\tau_{f}$ of $\mathrm{CaTiO}_{3}-\mathrm{LnAlO}_{3}(\mathrm{Ln}=\mathrm{La}, \mathrm{Nd})$ ceramics as a function of the sintering temperature.

Table. 1 Atomic percentage of $\mathrm{CaTiO}_{3}-\mathrm{LnAlO}_{3}(\mathrm{Ln}=\mathrm{La}, \mathrm{Nd})$ quantified from EDS spectra

\begin{tabular}{cccccc}
\hline Element Atomic (\%) & $\boldsymbol{C a}$ & $\boldsymbol{T i}$ & $\boldsymbol{L a} / \mathbf{N d}$ & $\boldsymbol{A l}$ & $\boldsymbol{O}$ \\
& & & & & \\
\hline CTLA & 18.76 & 20.09 & 10.19 & 10.09 & 40.87 \\
CTNA & 19.85 & 20.77 & 9.94 & 7.76 & 41.68 \\
\hline
\end{tabular}



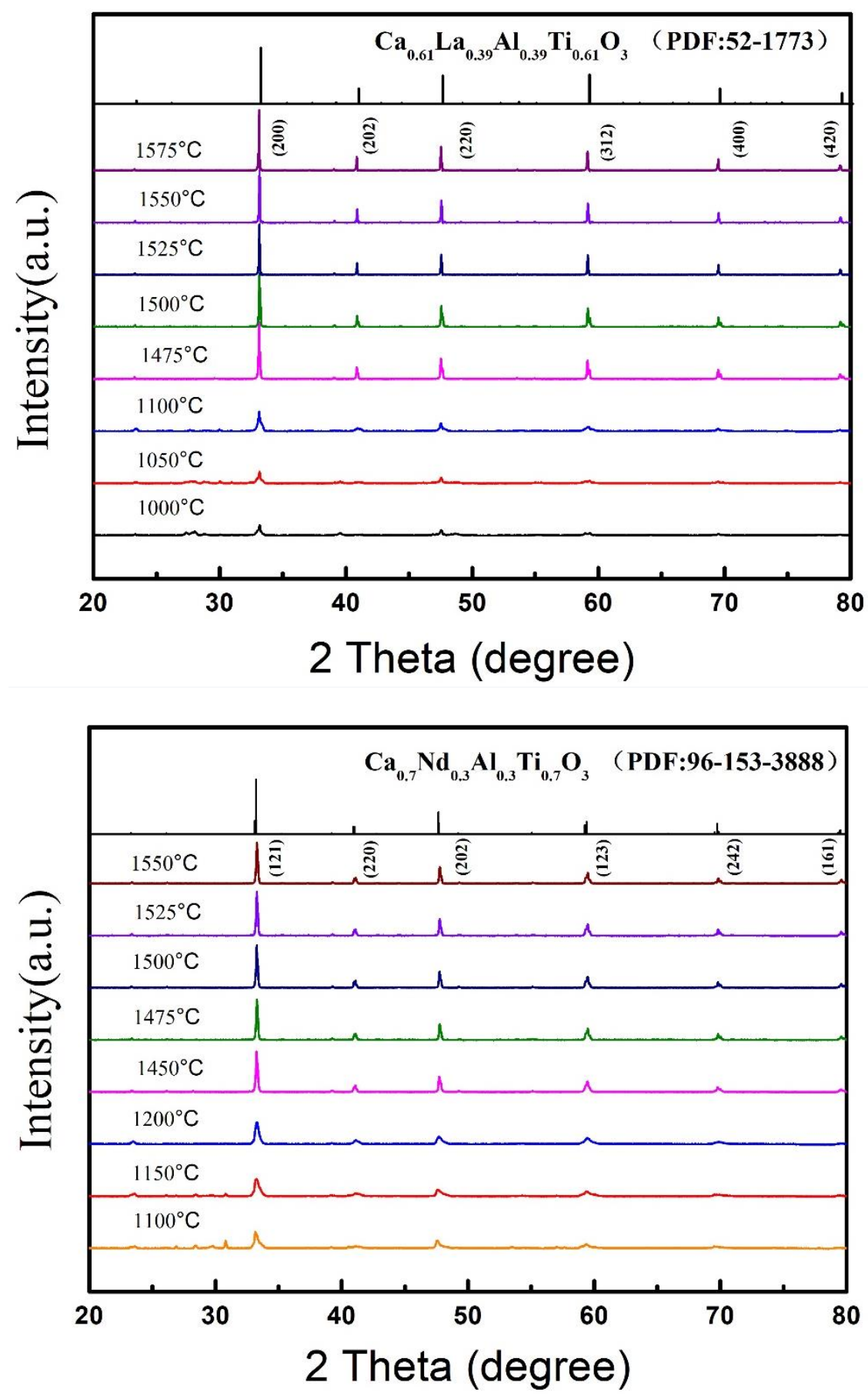

Figure 1 

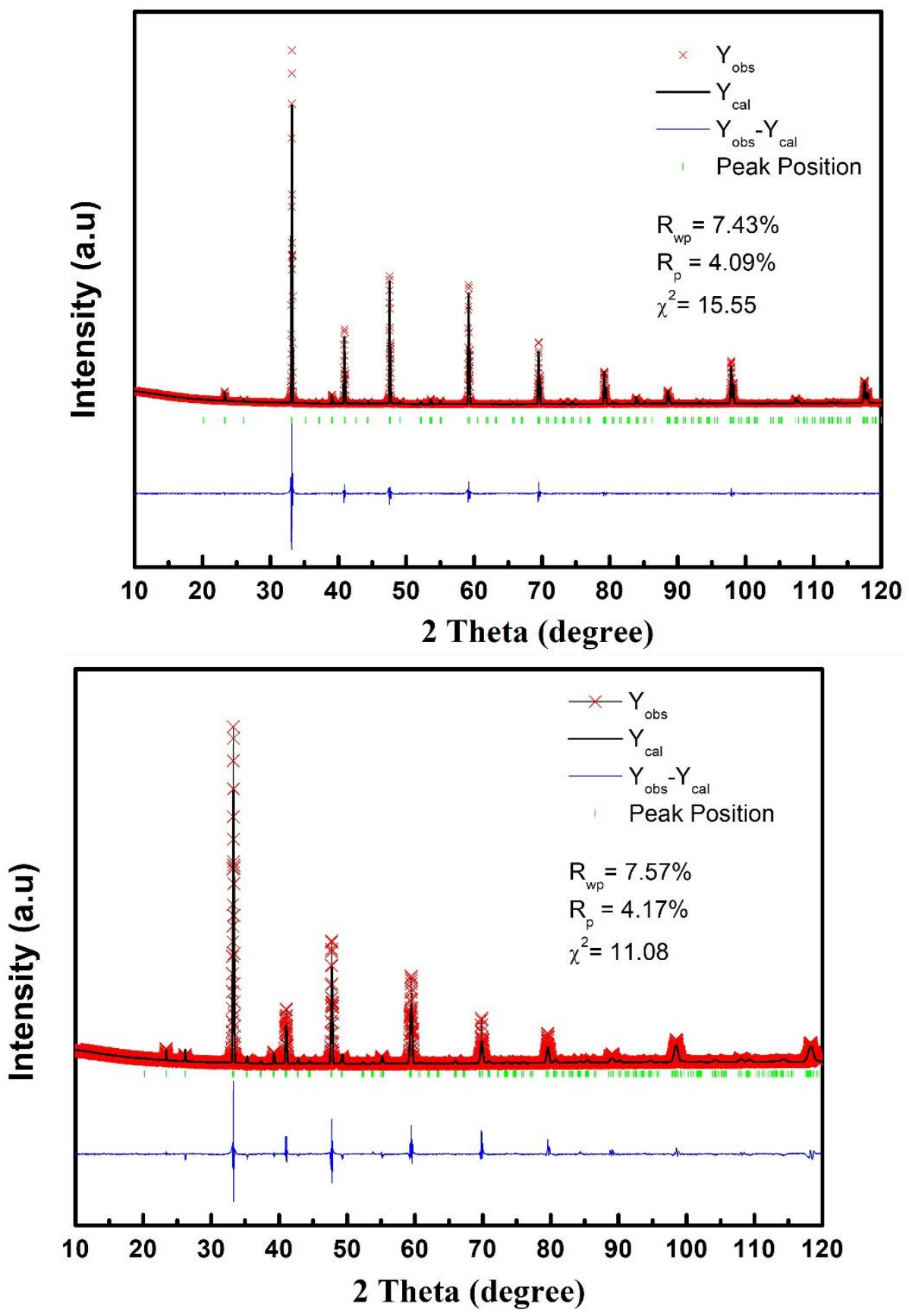

Figure 2 

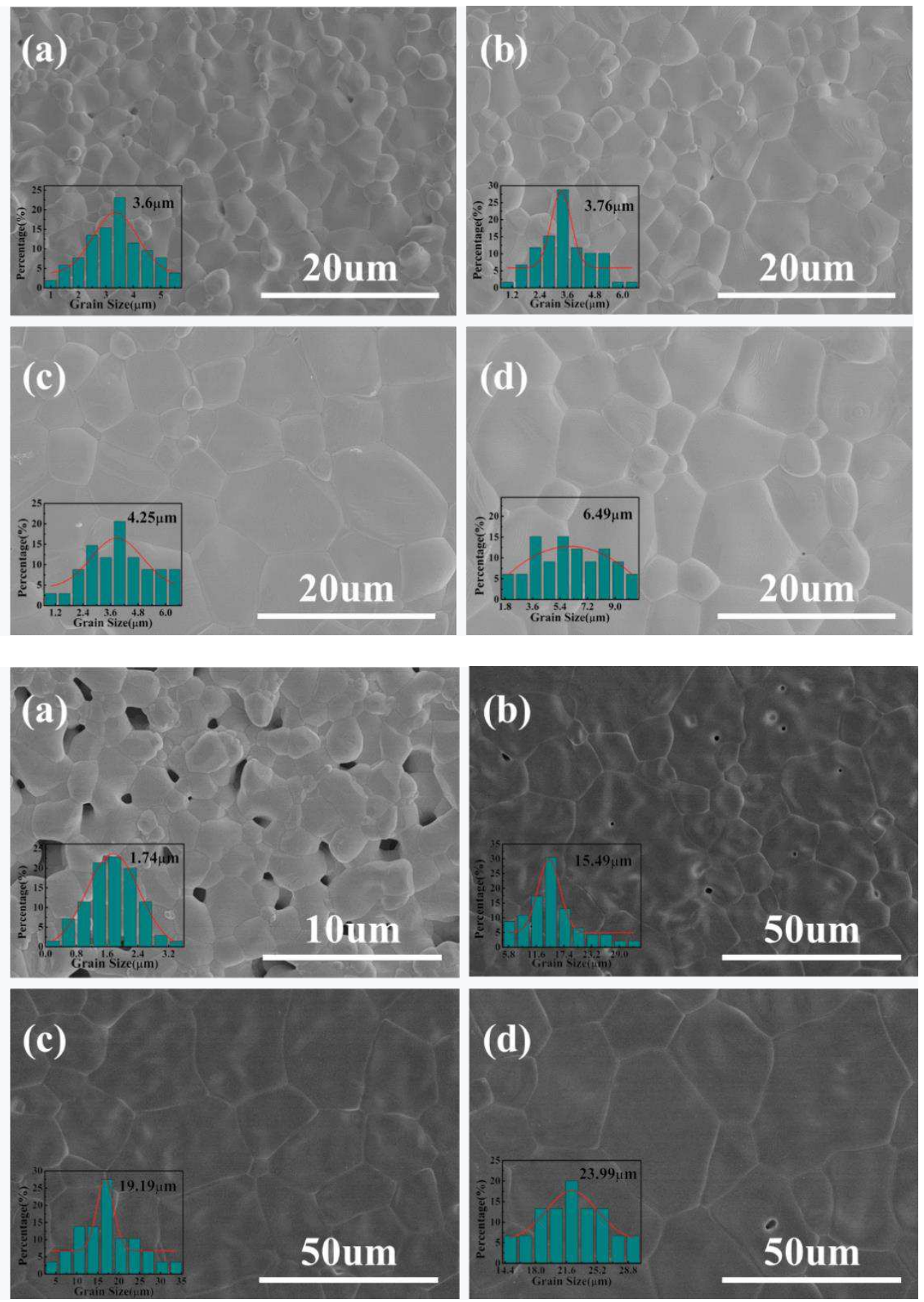

Figure 3 

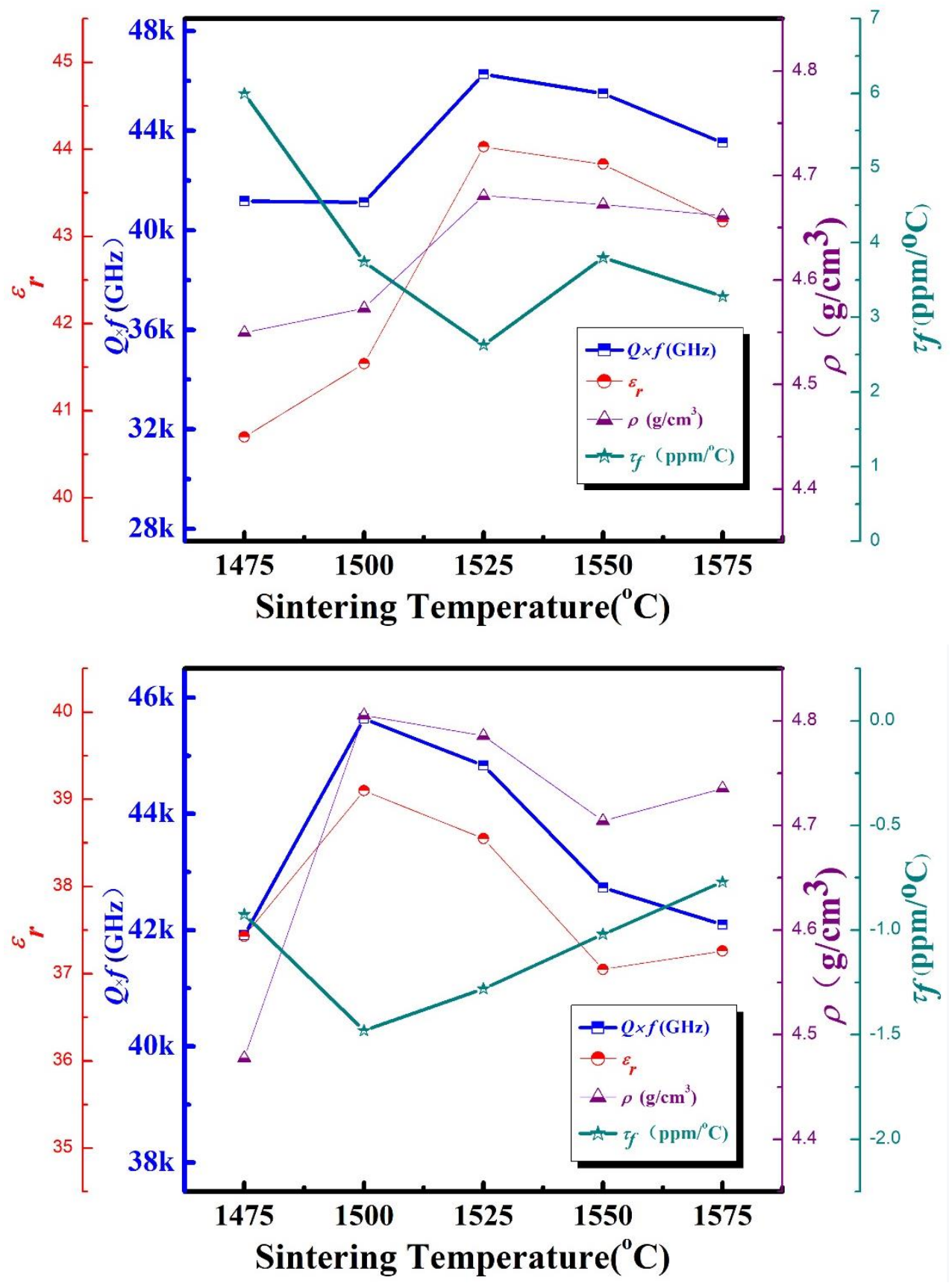

Figure 4 

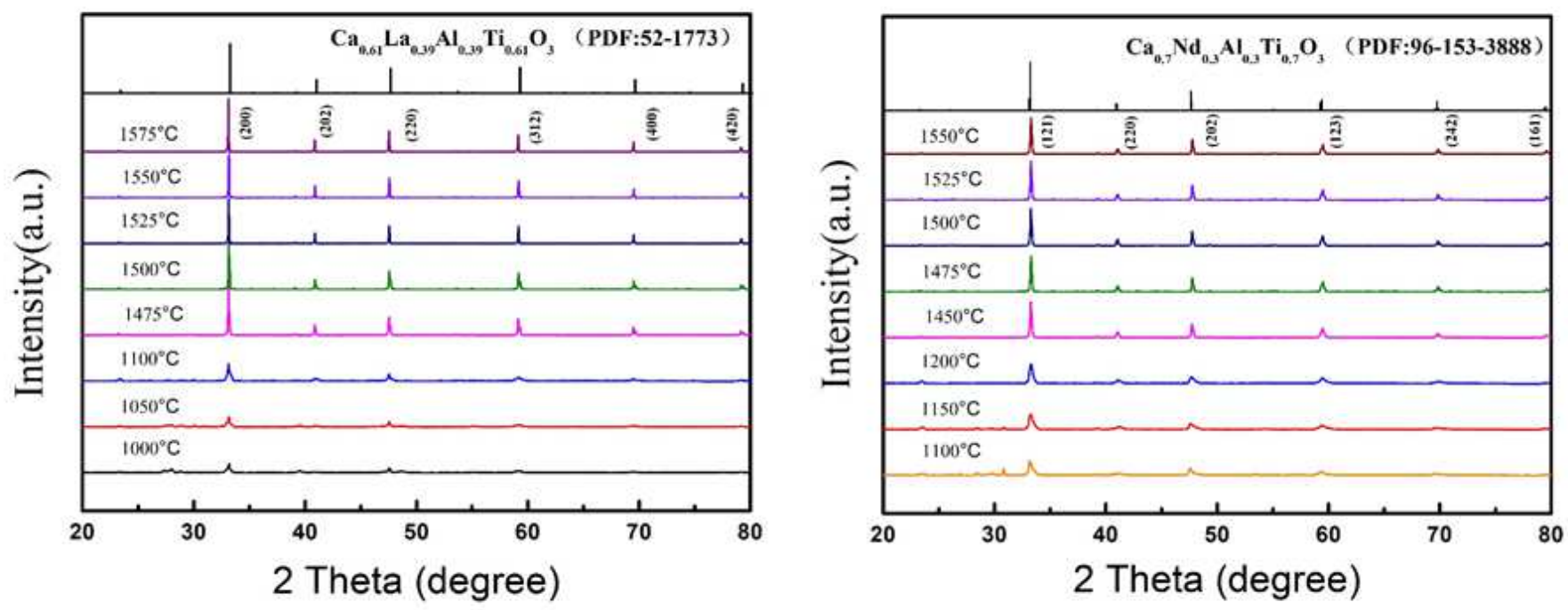

Figure 1

XRD patterns of CTLA and CTNA ceramics sintered at 1100 to $1575^{\circ} \mathrm{C}$ for $6 \mathrm{~h}$.
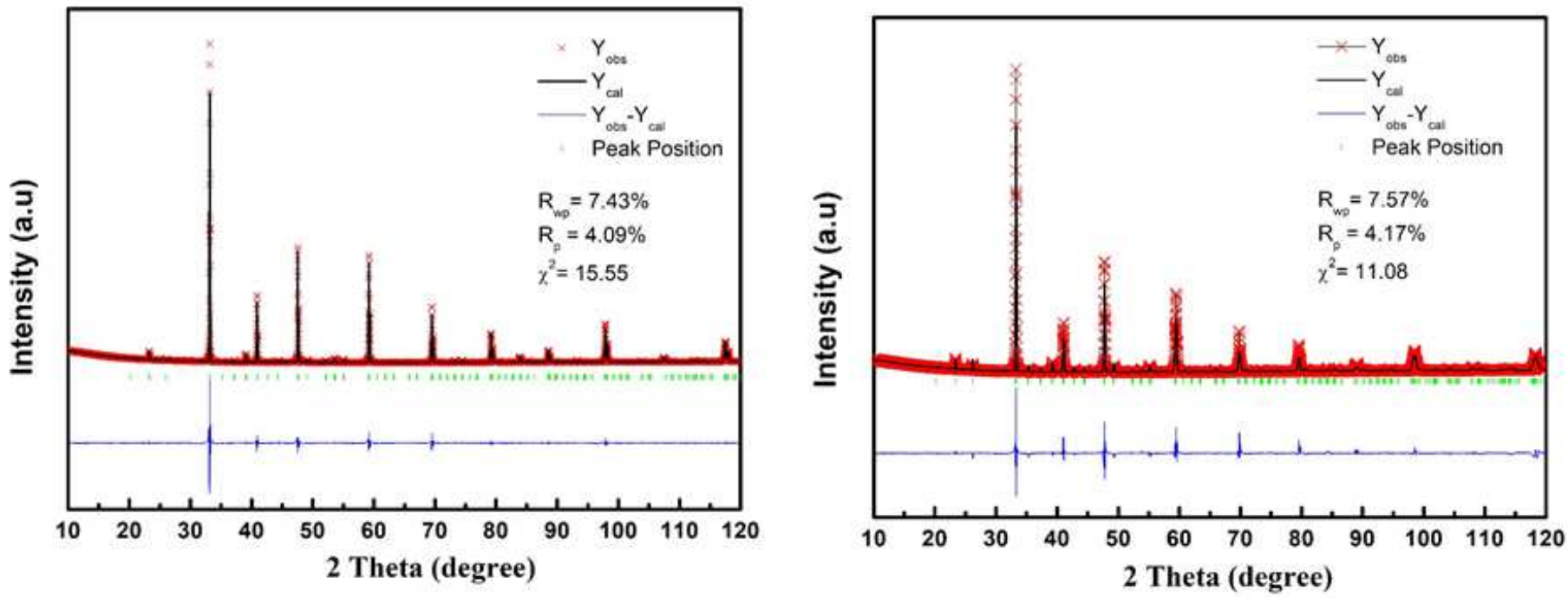

Figure 2

Rietveld refinement of the room temperature XRD patterns of CaTiO3-LnAIO3(Ln=La, Nd) ceramic (CTLA: $R p=4.09 \%, \operatorname{Rwp}=7.43 \%, \nabla 2=15.55 ;$ CTNA: Rwp $=7.57 \%, R p=4.17 \%, \nabla 2=11.08)$. 

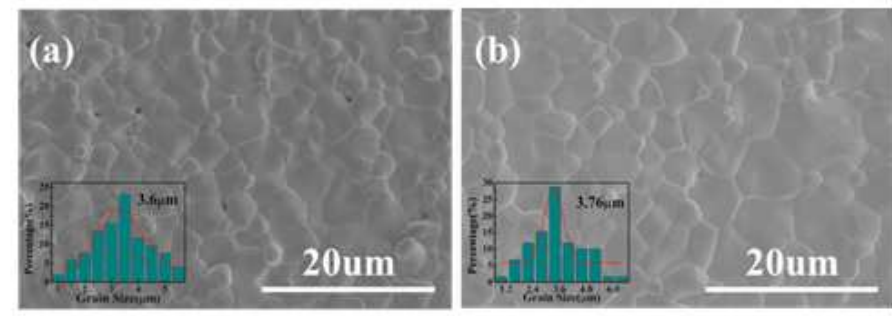

(c)

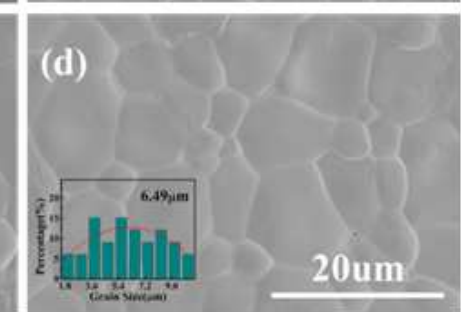

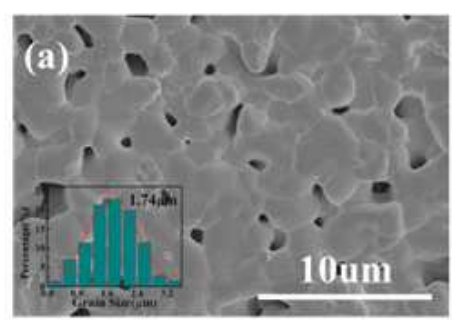

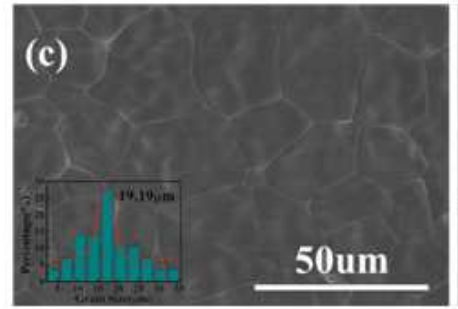

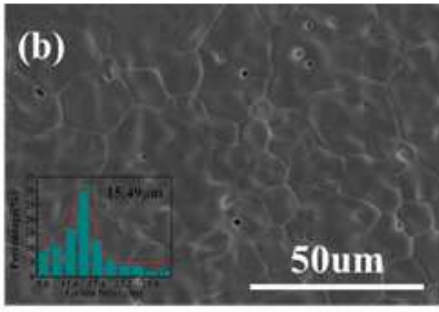

(d)

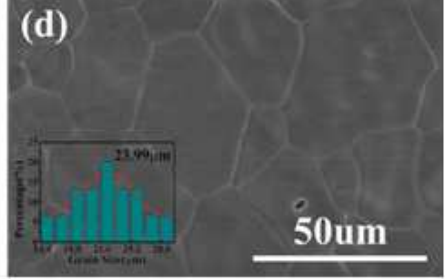

\section{Figure 3}

SEM micrographs of CaTiO3-LnAlO3(Ln=La, Nd) ceramics sintered at 1475 to $1550^{\circ} \mathrm{C}$ for $6 \mathrm{~h}$.
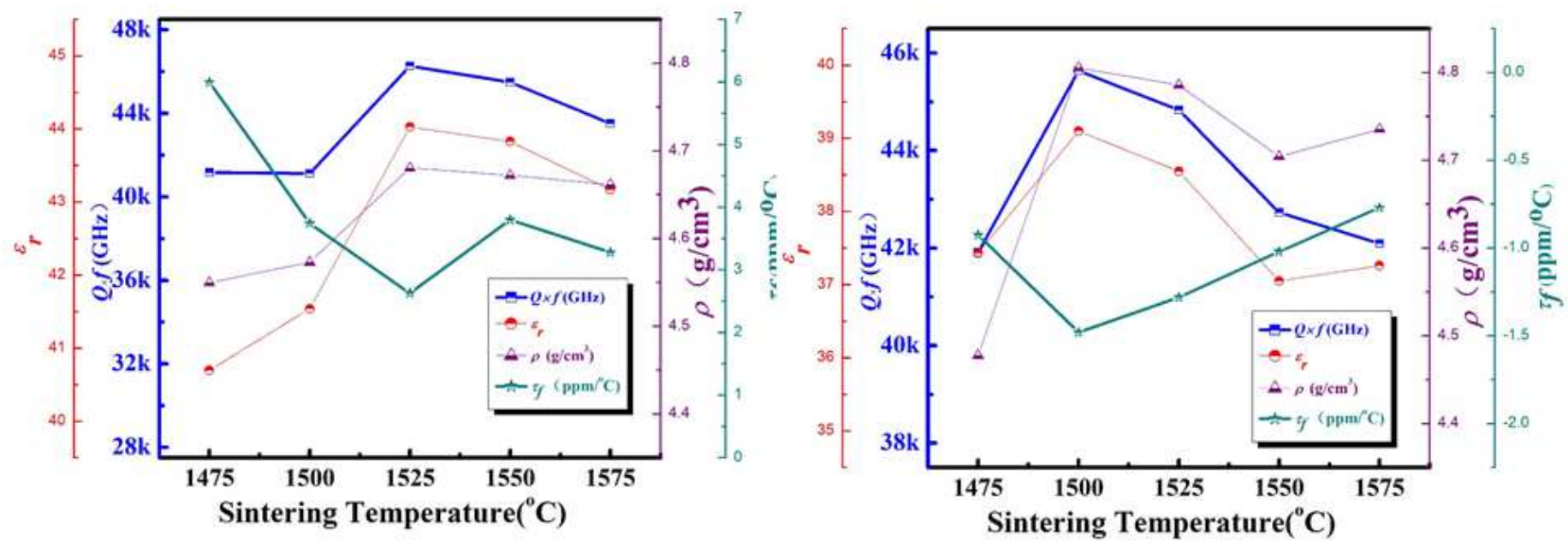

Figure 4

The curves of $\rho, \varepsilon r$, Q $\times f$ and $t f$ of CaTiO3-LnAlO3( $\mathrm{Ln}=\mathrm{La}, \mathrm{Nd})$ ceramics as a function of the sintering temperature. 